\title{
5. 内外におけるモニタリングの実用例
}

\section{Some Examples of Practical Applications in Corrosion Monitoring}

\section{1 内 燃 機 関 冷 却 水 系 統}

\author{
露木昭 治* \\ *鉄道技術研究所
5. 1 Application of Corrosion Monitoring Methods to Engine Cooling Systems \\ Shoji Tsuyuki* \\ *Railway Technical Research Institute, JNR
}

\begin{abstract}
This paper deals with some examples of application of methods for monitoring of corrosion of metals to engine cooling systems. In service tests of a simulated automobile cooling system linear polarization methods in-situ were applied to the measurements of corrosion rates of aluminum specimens and aluminum water pumps immersed in inhibited ethylenglycol coolant under operating conditions. It was found that rates of corrosion of $\mathrm{Al}$ estimated from the polarization measurements correlated well with the actual weight losses. Periodic linear polarization measurements made in service tests continued for 7 months (running distance: $11,300 \mathrm{kms}$ ) under cooling conditions similar to practical ones showed that the estimated corrosion rates of the aluminum were in a good agreement with the average corrosion rate calculated from the weight losses of aluminum specimens removed from the test cars. The linear polarization resistance method for monitoring of corrosion of metals in diesel locomotive cooling system and an electronic sensor for detecting of the corrosivity of automobile antifreezing coolants are also described.
\end{abstract}

\subsection{1 まえがき}

自動車, 車両, 船舶等の機関冷却水系統に和ける腐食 問題はよく知られて敊り, 水, 不凍液（エチンングリコ 一ル）または海水により, 機関, 熱交換器類その他構成 部品が腐食される。通常, 使用されている冷却水用イン ヒビターは温度, 流速, 圧力等の影響により防食機能が 破壊されて不慮の腐食事故になることがあるので，局部 腐食機構の検討とともに防食管理面から腐食モニタリン グに関心がもたれてきた。ここでは電気的計測による腐 食モニタリングの開発研究に掂いて, 実用上の重要な指 針と考えられる二，三の実験例について述べる。

\subsection{2 自 動 車}

(1) シミュレーション試験

自動車の冷却水系統に批ける腐食をモニタ一するため に, M.S. Walker により図 5.1.1 に示すシミュレーシ ヨン試験装置が考案された1)。この装置に組み込まれた

* 干185 国分寺市光町 2-180 (2-180, Hikari-cho, Kokubunji, Tokyo 185, Japan)
直線分極抵抗法（定電流方式）により各種条件下のエチ レングリコールクーラント中の鋳鉄, 黄銅, はんだ, ア ルミニウム鋳物試験片の腐食速度が測定され, 重量減測 定法による結果とよく一致することが明らかにされた。 これらの試駼結果の一部は既に本誌に紹介されているの で参照されたい2。

また本装置に組み込まれたアルミニウム製水ポンプ抒 よびアルミニウム製サーモスタットハウジングを対象に たとえば図5.1.2 亿示すような電極構成として,これらに 対する直線分極抵抗法の適用性が検討された。実験の一 例として，クーラントの流速を 180 時間ごとに変えた場 合の試験結果を図 5.1.3 に示す。水ポンプの腐食速度が 低流速 $(48 \mathrm{l} / \mathrm{min})$ で小さいのに比へ, 高流速 $(108 \mathrm{l} / \mathrm{min})$ では大きくかつ激しく変化している。この変動はキャビ テーションの発生による周期的な酸化皮膜の破壞と補修 が行われていることを暗示しており，本法による測定結 果から, 水ポンプのキャビテーション損傷を防止するあ る限界流速を推定できるとともに，キャビテーション腐 食に対するモニタリングにも役立つことがわかる。 


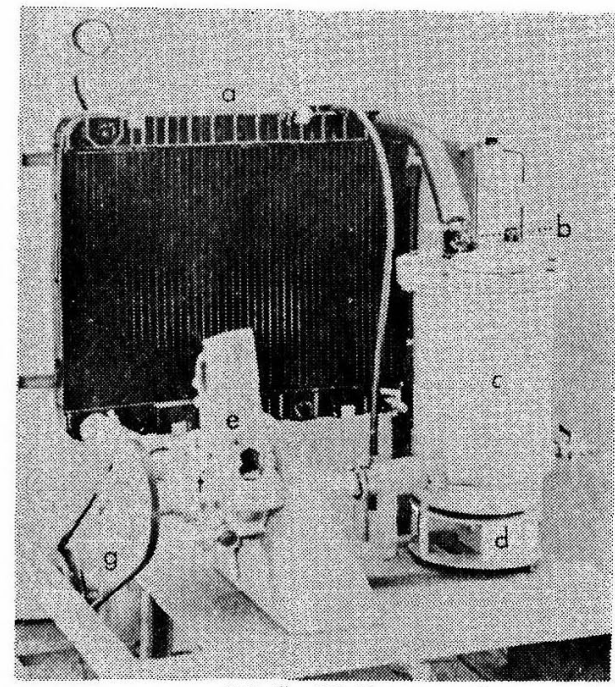

(M. S. Walker et al. による)

図 5.1.1 白動車のシミュレーション試駼装置 (a) ラ ジエータ (b) サーモスタットハウジング (c) メタポット（エンジンブロッ夕をシ ミュレートしたもの) (d) ホットプレート (e) タイミングテェンカバ- (f) 水ポンプ (g) 電動モーター

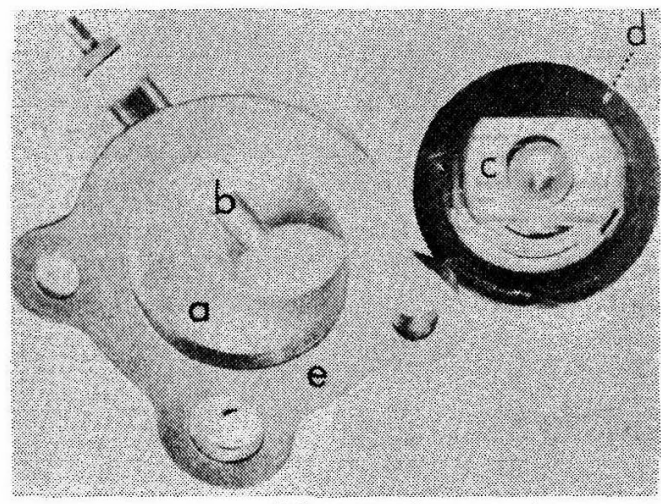

(M.S. Walker et al. による)

図 5.1.2 サーモスタットハウジングに护ける直線 分極抵抗の测定用電極の納立て

(a) サーモスタットハウジング (試料 電極)，(b) 白金照合電極，(c) サ一モス夕 ット (対極)，(d) 絶縁被覆，(e) 絶縁用ガ スケット

\section{(2) 実車試験}

白動車による約 1 年間の箩車試験を行い，この間，周 期的に测定した直線分極抵抗法によるデータと試踢片の 重量娍から求めた腐食速度を対比した。試験条件として はクーラント温度は常温から $82^{\circ} \mathrm{C}$, 流速は $0 \sim 2.2 l / \mathrm{s}$, 压加は大気压から $9,800 \mathrm{~kg} / \mathrm{m}^{2}$ で，最高速度は $96 \mathrm{~km} / \mathrm{h}$ である。試䶀片はラジェータ下部のゴムホース中間に鋳 鉄，黄銅はんだおよびアルミニウム鋳物をセットし，

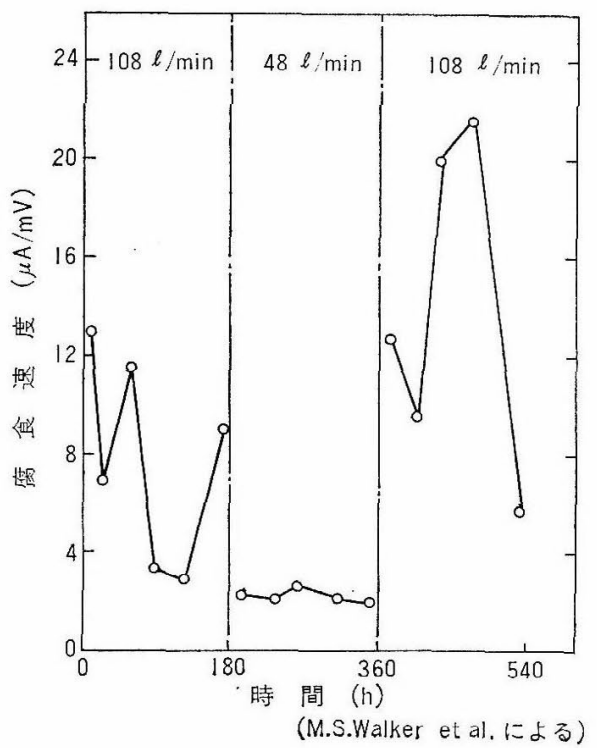

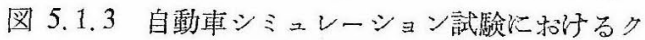
ーラントの流速を変觉たときのアルミニ ウム製水ポンプの腐食速度

クーラント：25\% GM 6038-M エチレン グリコール, $82^{\circ} \mathrm{C}$

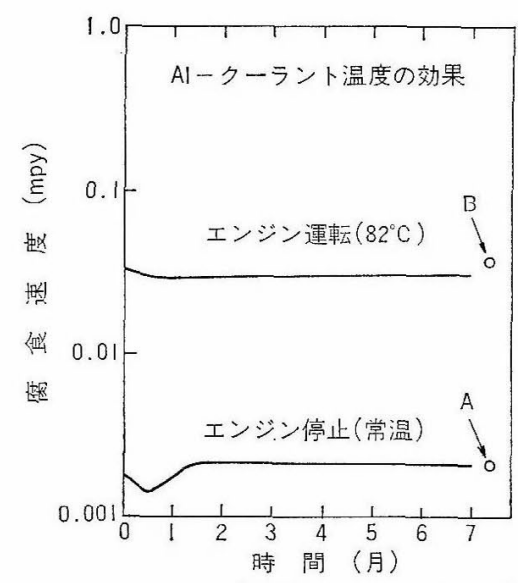

(M.S.Walker et al.による)

図 5.1 .4 試験期間 7 か月, $11,300 \mathrm{~km}$ 走行の实車 試驗に和计る直線分極抵抗法により求め たアルミニウムの鹰食速度および重量減 から求めたアルミニウムの平均腐食速度 (A および B 点)

分極測定装置恃測定時以外は取り外し，七ルのみを残し て晸転した。

㱏駼結果の一例を図 5.1.4 K示与。図中の点A 11 車 両による 12 か月閪の平均 $19,300 \mathrm{~km}$ 運転後のアルミニ ウムの重量減から求めた腐食速度の平均值を示し, 点 $\mathrm{B}$ は 10 車両による 8 か月間, 平均 $80,450 \mathrm{~km}$ 運転のもの でめる。これらからアルミニウムの噟食速度はェンジン 
停止時に比べて，運転時に著しく大きくまたこれらの

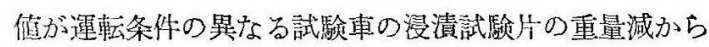
求められた腐食速度に対応していることが認められた。

\section{（3）特殊センサーによるクーラントの腐食性モニタ}

クーラントが噟食性に变化したかどらかを判䉼少る自 動車给却水用腐食モニター装置が Texas Instruments によって開発された。これK使用されているセンサーは 腐食㳂中での金属に発生する固有の電位を利用したるの でこれと照合電極間に生ずる電位すなわちせンサー電 位とクーラントの腐食性充なは防食性との間に相互関係 が得られている。たとえば，正常なインヒビター溶液の 埸合では $-0.2 \mathrm{~V}$ 附近の電位を示するのが, $-0.4 \mathrm{~V}$ 近 くで部分的な防食性能の低下と判制される。きたエチ レングリコール溶液は腐食性が大きく，七ンサ一電位は -0.7〜ー0.8V 示す。任意のセンサー電位に警告表示 をセットすることができ，これよりインヒビターの補給 またはクーラントの取替えをドライバーに知らせること ができる。

\subsection{3 ディーゼル機関}

ディーゼル車両の冷却水系統の防食管理にはインヒビ ターの濃度分析や $\mathrm{pH}$ 測定による間接モニタリング法が 実施されている。しかし，局部腐食防止対策の研究や冷 却水防食処理の近代化のために, 電気化学的腐食モ二夕 リングに対して関心が劄せられるようになってきた。最 近，国鉄て㳊筆者らにより図 5.1 .5 亿示与窝食計（定電 流方式の值線分極抵抗法）の車阙用ディーゼル機関冷却 水系絩の腐食モニタリングのの適用性について寒本試験 によって検討している。

図 5.1.6 はインヒビターを添加した $15 \mathrm{v} / \mathrm{v} \%$ エチレン グリコールクーラント(冷却水容量約 1,000l) 中の鋼の 腐食速度と只の関連データを示す。鋼の腐食速度は初期 に0.1 0.4 mdd の範国に变動したが, 次第に定常値を示

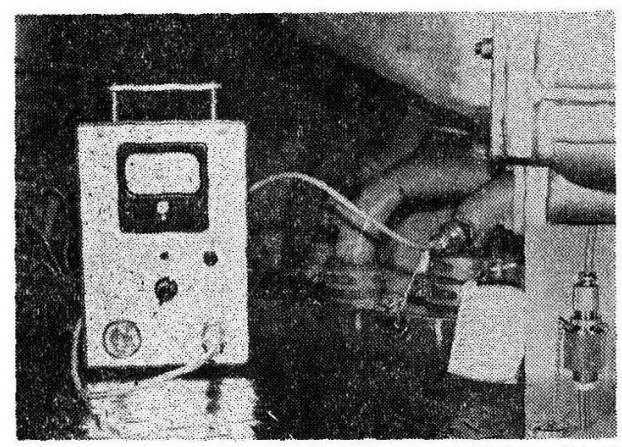

図 5.1.5 腐食計および直線分極抵抗測定用電極之 そのディーゼル機関泠却水管への取付け 状热

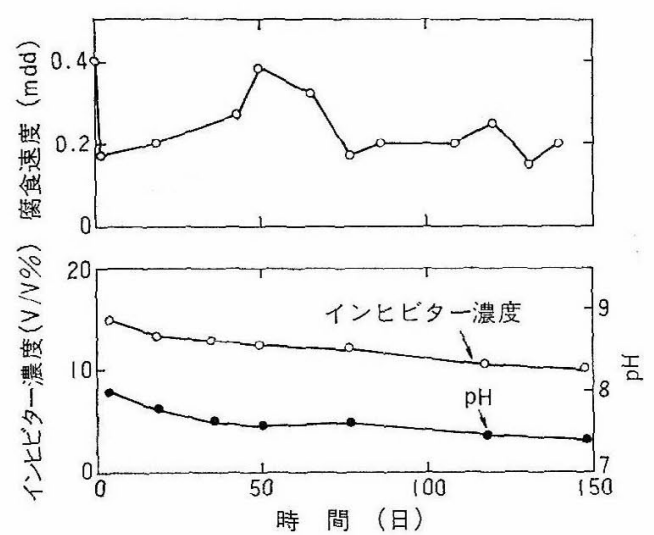

図 5.1.6 DE 10 型ディーゼル機関車泠却水系統に 和ける直線分極抵抗法による鋼の腐食速 度, インヒビタ一濃度および $\mathrm{pH}$ の変化

すようになった。これらの変動に対しては補給水による インヒビターの濃度低下や $\mathrm{pH}$ 変化との影響は小さく, もしろ分極測定時の佮却水温により变わり, 高温のとさ に大きい値を示すものと考えられる。本法による腐食モ ニタリングにおける今後の問題点として，アルミニウム 合金队銅合金電極に上る分極測定データの集收とそれら の信頼性について検討し，インヒビターの破䘫や補給水 泣よる防食性能の低下を簡易に判断できるよらな腐食性 警告琵示条件の沠定などがあげらるる。

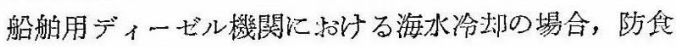
対策に流電陽極法が採用されるときには，腐食モニタリ ングとして防食電位計測法が墑当と思秃れるが, 詳細に ついては他の電気防食法に関する記述を参照されたい。

エンジンクーラント系の腐食モニタリングについて無 抵抗電流計によるガルバ二電流計测方式る検討されてお り，適切な手段と考觉られるが，本法の多電極系への適 用条件などに問題があり，研究段階にあると思われる。

以上，エンジン冷却水系統に和计る電気的計測方法に よる二, 三の腐食モニタリングの実験例について述べた が、いずれる開発研究のための笑車試験段階にあり， 死 と九ど篹用されていないのが靦状であるら。しかし， エ

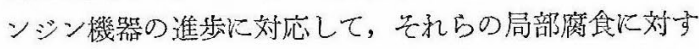
る直接腐食モニタリングの研究とともに，さらに間接腐 食 (防食) モニタリングの実用化について検傠する必要 があるら。

\section{(昭和 53 年 11 月 6 日受理)}

\section{文南}

1) M.S. Walker \& W. D. France: Mater. Perform., 8, No. 9, 47 (1969).

2) 露木昭治: 防蝕技術, 21, No. 1, 3 (1972).

3) M.S. Walker: Mater. Perform., 13, No. 7, 37 (1974). 